\title{
Perlindungan Hukum Anak dan Istri dalam Perkawinan Siri di Kecamatan Proppo Kabupaten Pamekasan
}

\author{
Umi Supraptiningsih \\ (Jurusan Syari'ah STAIN Pamekasan, Jln. Panglegur Km. 04 Pamekasan, \\ Email: umistainpamekasan@gmail.com)
}

\begin{abstract}
Abstrak:
Dalam rangka untuk mempertahankan dan memenuhi kebutuhan dan kelangsungan hidupnya, perempuan bersedia untuk menjadi isteri kedua atau ketiga bahkan keempat dengan status perkawinan siri. Mereka sadar dan paham bahwa perkawinan yang dilakukan secara siri mempunyai konsekuensi dan resiko terhadap diri dan keturunannya. Perempuan hanyalah membutuhkan jaminan untuk kelangsungan hidupnya dan keturunannya. Peristiwa semacam ini sudah menjadi hal yang umum dan biasa terjadi pada masyarakat pedesaan di Kecamatan Proppo Kabupaten Pamekasan. Mereka hanya memahami bahwa inilah kehidupan rumah tangga yang harus dilakukan untuk meneruskan kehidupan dan keberlangsungan keturunannya. Tanpa memikirkan bagaimana dengan hak-hak mereka serta keturunannya. Masa depan keturunannya yang tentunya sangat panjang sering terabaikan, karena mereka hanya memikirkan ketercukupan sesaat. Perlindungan hukum terhadap anak serta perempuan yang dipoligami dan dinikahi siri, tidak diperoleh baik perlindungan dalam bidang administrasi, perdata maupun pidana.
\end{abstract}

\section{Kata Kunci:}

Perlindungan, Anak, Istri, Poligami, Siri

\begin{abstract}
:
In order to maintain and meet the needs and survival, women are willing to become second or third wives even fourth series marital status. They are aware and understand that marriage is done siri have consequences and risks to themselves and their offspring. Women just need a guarantee of survival and offspring. The events of this kind have become commonplace and are common in rural communities in subdistrict Proppo of Pamekasan. They just understand that this is the home life should be made to continue the life and the sustainability of the offspring. Without thinking about what their rights as well as their
\end{abstract}


descendants. The future is certainly very long offspring often overlooked because they only think about the adequacy moment. Legal protection of children and women of polygamy and married siri, not gained both protection in the field of administrative, civil and criminal.

\section{Keywords:}

Protection, Child, Wife, Poligami, Siri

\section{Pendahuluan}

Kekerasan terhadap perempuan dari hari ke hari semakin meningkat, baik kekerasan yang terjadi dalam lingkup keluarga maupun diluar keluarga. Apa yang sebenarnya melatarbelakangi kasus-kasus kekerasan terhadap perempuan? Ada anggapan bahwa pemerintah menerbitkan berbagai peraturan dan penjatuhan sanksi terhadap pelaku kekerasan terhadap perempuan, namun justru menyebabkan kasus-kasus kekerasan semakin meningkat. Anggapan tersebut tidak tepat karena sebelum pengaturan dan penjatuhan sanksi diterapkan, kasus-kasus kekerasan terhadap perempuan sudah banyak terjadi. Persoalannya masyarakat beranggapan bahwa pertengkaran suami isteri dalam rumah tangga adalah persoalan privasi keluarga masing-masing. Dengan aturan tentang Penghapusan Kekerasan dalam Rumah Tangga (PKDRT) dalam Undang-Undang No. 23/2004, baik perempuan sendiri maupun masyarakat dapat membawa kasus tersebut ke ranah hukum meskipun tidak secara otomatis mengurangi kasus KDRT tetapi justru lebih meningkat.

Banyak faktor yang melatarbelakangi terjadinya kekerasan terhadap perempuan, antara lain karena perempuan secara kodrati lemah dibandingkan dengan lelaki, perempuan yang selalu menggantungkan hidupnya pada lelaki terutama dalam bidang ekonomi. Ketidakmandirian perempuan merupakan kondisi yang dimanfaatkan oleh lelaki untuk menguasai perempuan baik secara fisik maupun non fisik.

Dalam beberapa kasus, untuk mempertahankan dan memenuhi kebutuhan dan kelangsungan hidupnya, perempuan terpaksa bersedia untuk menjadi isteri kedua atau ketiga bahkan keempat dengan status perkawinan siri. Mereka memahami, bahwa perkawinan yang dilakukan secara siri mempunyai 
konsekuensi dan resiko terhadap diri dan keturunannya. Yang dibutuhkan perempuan hanya bagaimana mereka mempunyai jaminan dapat belanja tiap hari tanpa harus susah bekerja. Selain itu, walaupun perkawinannya dilakukan secara siri, ada kebanggaan tersendiri bila keturunannya memiliki darah dari seorang tokoh atau ulama. Bagai simbiosis mutualisme, lelaki merasa nyaman dengan poligami dan perkawinan siri yang dilakukan dan perempuan merasa kelangsungan hidupnya dapat berlangsung dalam satu imajinasi sosial tertentu. Hal semacam itu sudah menjadi peristiwa yang umum dan biasa terjadi pada masyarakat pedesaan di Kecamatan Proppo, Kabupaten Pamekasan.

Ketidakmandirian perempuan dibidang ekonomi, berawal dari tingkat pendidikan perempuan pedesaan yang rendah serta kultur masyarakat pedesaan yang tradisional. Perempuan selalu dinomorduakan dengan cukup menempuh pendidikan di Madratsah Ibtidaiyah (MI) dan dilanjutkan ke pesantren yang hanya bertujuan untuk menunggu jodoh. Mereka minim akses informasi dan komunikasi dengan lingkungan yang lebih luas dan hanya berkutat dalam pergaulan di lingkungannya sendiri yang sangat terbatas. Akibatnya yang terjadi pada perempuan-perempuan pedesaan ini adalah ironi: "inilah garis hidup dan kehidupan saya, asalkan tetap bisa melangsungkan hidup dan mempunyai keturunan dari tokoh yang mempunyai kharisma".

Mereka menerima "jalan hidup" dan tidak melakukan tuntutan apapun. Apakah perilaku ini salah satu tradisi yang sudah terbangun dengan kuatnya sehingga mereka menganggap sebagai perilaku yang normal? Para perempuan ini hidup dalam doktrin masa lalu di saat mereka hidup dalam zaman yang mengalami perubahan dan perkembangan. Perkembangan pembangunan, pendidikan, sosial, ekonomi bahkan budaya yang terus mengalami kemajuan yang menuntut hak-hak perempuan dan keturunannya dapat terpenuhi.

Kecamatan Proppo, secara geo-demografis berada di daerah pertengahan sebelah selatan dari wilayah Pamekasan. Kecamatan Proppo, Kabupaten Pamekasan merupakan salah satu Kecamatan di wilayah Kabupaten Pamekasan dengan jumlah penduduk 70.995 jiwa, sebanyak 34.241 jiwa laki-laki dan 36.754 jiwa perempuan. Dari jumlah perempuan yang lebih banyak dibanding laki-laki 
didominasi pada usia 25 tahun sampai 49 tahun yaitu sejumlah 11.631 jiwa. ${ }^{1}$ Kehidupan perekonomian masyarakatnya secara umum termasuk yang tertinggal dengan masyarakat lain di Kabupaten Pamekasan.

Ketertinggalan tersebut merupakan salah satu akibat dari persoalan rumit antara perempuan, kemiskinan, dan agama. Kalau kita menghubungkan antara kemiskinan dan agama, maka yang menjadi obyek, salah satunya, adalah perempuan. Dalam rangka untuk tetap hidup dan demi kepentingan anak, maka tidak sedikit perempuan terpaksa, merelakan diri untuk dipoligami dengan jalan pernikahan siri.

Dari hasil observasi terhadap para istri yang dipoligami dengan perkawinan siri tersebut, diperoleh beberapa temuan faktual. Di antaranya, mereka tidak mendapatkan hak-haknya sebagaimana mestinya. Mereka harus sembunyi-sembunyi untuk menjalani kehidupan berumahtangga dengan suaminya. Menariknya, terdapat resistensi dari lingkungannya terhadap pilihan hidup yang mereka jalani. Cibiran, cemoohan, sindiran dari lingkungan terhadap, harus dihadapi. Bahkan anak-anak hasil keturunan mereka juga turut mendapatkan perilaku yang kurang simpatik dari masyarakat. Namun demikian praktik poligami dengan perkawinan siri tetap saja berlangsung bahkan semakin subur dan terus bertambah dari hari ke hari.

Beberapa permasalahan yang perlu dilakukan pembahasan dalam tulisan ini, yaitu pertama: Bagaimana perlindungan hukum terhadap anak serta perempuan yang dipoligami dan dinikahi siri?; kedua : Bagaimana pemahaman perempuan pedesaan tentang poligami dan perkawinan siri serta akibat hukumnya?; ketiga Bagaimana kondisi rumah tangga perempuan pedesaan sebagai isteri poligami dengan status pernikahan siri?.

\section{Metode Penelitian}

Pendekatan dalam penelitian ini menggunakan pendekatan kualitatif (qualitative approach) karena data yang dikumpulkan lebih banyak menggunakan data kualitatif yakni data yang disajikan dalam

\footnotetext{
1 Badan Pusat Statistik Kabupaten Pamekasan, Kabupaten Pamekasan Dalam Angka, tahun 2009.
} 
bentuk verbal bukan dalam bentuk angka ${ }^{2}$ yang semaksimal mungkin berusaha mendeskripsikan realitas aslinya untuk kemudian data dimaksud dianalisis dan diabstraksikan dalam bentuk teori sebagai tujuan finalnya.

Selain pendekatan kualitatif yang dipergunakan dalam penelitian ini, peneliti juga menggunakan pendekatan-pendekatan dalam penelitian hukum yaitu pendekatan undang-undang (statute approach), pendekatan kasus (case approach), pendekatan historis (historical approach), dan pendekatan konseptual (conceptual approach). ${ }^{3}$

Lokasi penelitian dilakukan di 2 (dua) Desa yaitu Desa Klampar dan Desa Rangperang Daya, Kecamatan Proppo, Kabupaten Pamekasan. Pemilihan lokasi ini didasarkan bahwa di 2 (dua) Desa tersebut banyak terjadi perempuan yang dipoligami dengan perkawinan siri.

Data penelitian dikumpulkan dengan metode interaktif dan noninteraktif. Metode interaktif dilakukan pada saat melakukan wawancara mendalam dan observasi partisipasi, sedangkan metode noninteraktif diarahkan pada analisis isi dokumen. Penggunaan wawancara, observasi, dan dokumentasi sebagai teknik pengumpulan data dimaksudkan untuk memperoleh data yang holistik dan integratif tentang fokus penelitian. Ketiga teknik pengumpulan data ini merupakan teknik dasar dalam penelitian kualitatif.

\section{Perlindungan Hukum terhadap Anak serta Perempuan yang Dipoligami dan Dinikahi secara Siri}

Istilah "perlindungan hukum" dalam bahasa Inggris kita dapatkan padanannya, yaitu legal protection, sedangkan dalam bahasa Belanda, yaitu rechtsbecherming. "Perlindungan Hukum" yang terdiri dari dua kosa kata tersebut tidaklah selalu mempunyai pemaknaan yang sama, tergantung kalimat berikutnya yang mengikuti kata-kata perlindungan hukum.

\footnotetext{
2 Noeng Muhadjir, Metode Penelitian Kualitatif, (Yogyakarta: Rake Sarasin, 1996), 29.

3 Peter Mahmud Marzuki, Penelitian Hukum (Jakarta : Kencana Prenada Media Group, 2005), 92

4 Harjono, Perlindungan Hukum (Membangun sebuah konsep Hukum) - dalam Konstitusi Sebagai Rumah Bangsa, (Jakarta: Sekretariat Jenderal dan Kepaniteraan Mahkamah Konstitusi, 2008), 374
} 
Berkaitan dengan pengertian perlindungan hukum ini, ada dua aspek yang perlu diperhatikan: pertama: jika sasaran perlindungan hukum lebih pada subyek atau orang, maka mempunyai pengertian bahwa harus menempatkan perlindungan hukum tersebut pada hak-hak seseorang yang harus dipenuhi oleh pihak atau orang lain. Kedua: bilamana perlindungan hukum sasarannya pada obyek atau benda, maka lebih pada bagaimana obyek tersebut menjadi aman, tidak ada pihak yang mengusik atau mengganggu dan bermanfaat sesuai dengan fungsi obyek atau benda tersebut. Dalam konteks perlindungan hukum terhadap anak, penekanannya pada perlindungan hukum atas hak-hak seseorang anak yang harus dipenuhi oleh pihak atau orang lain, seperti dari orang tua, masyarakat dan negara.

Perlindungan hukum tiada lain kecuali dimaknai sebagai perlindungan dengan menggunakan sarana hukum atau perlindungan yang diberikan oleh hukum. ${ }^{5}$ Tugas negara dalam rangka mensejahterakan rakyat dengan cara memberikan perlindungan hak bagi setiap rakyat Indonesia serta rakyat berkewajiban untuk mentaati hak orang lain dan mematuhi segala aturan yang ada di suatu negara. Bukti perlindungan negara terhadap rakyat sebagaimana disebutkan dalam ketentuan pasal 27 dan pasal 28, 28A sampai dengan 28I UUD 1945. Philipus M. Hadjon menyatakan bahwa "prinsip perlindungan hkum bagi rakyat terhadap tindak pemerintah bertumpu dan bersumber dar konsep tentang pengakuan dan perlindungan terhadap hak-hak asasi manusia diarahkan pada pembatasan-pembatasan dan peletakan kewajiban pada masyarakat dan pemerintah."6 Dalam konteks perlindungan hukum, hukum tidak hanya semata-mata menjaga ketertiban dan kepastian hukum saja, melainkan menentukan arah, membentuk, dan berusaha mewujudkan masyarakat yang hendak

\footnotetext{
5 Ibid., 375

6 Philipus M. Hadjon, Perlindungan Rakyat Bagi Rakyat di Indonesia (Sebuah Studi tentang Prinsip-Prinsipnya, Penanganannya oleh Pengadilan dalam Lingkungan Peradilan Umum dan Pembentukan Peradilan Administrasi Negara), (Surabaya: PT. Bina Ilmu, 1987), 38
} 
dicapai sesuai dengan tujuan bernegara, yakni masyarakat yang sejahtera. ${ }^{7}$

Ada beberapa fungsi hukum menurut Sjachran Basah, yaitu : (1) direktif, sebagai pengarah dalam membangun untuk mambentuk masyarakat yang hendak dicapai sesuai dengan tujuan kehidupan bernegara; (2) integratif, sebagai pemelihara (termasuk ke dalamnya hasil-hasil pembangunan) dan menjaga keselarasan, keserasian, dan keseimbangan dalam kehidupan bernegara dan bermasyarakat; (3) prespektif, sebagai penyempurnaan, baik terhadap sikap tindak warga, apabila terjadi pertentangan dalam kehidupan bernegara dan bermasyarakat; dan (4) korektif, sebagai pengoreksi atas sikap tindak, baik administrasi negara maupun warga, apabila terjadi pertentangan hak dan kewajiban untuk mendapatkan keadilan. ${ }^{8}$

Sedangkan fungsi hukum adalah untuk memberikan perlindungan, Lili Rasjidi dan B. Arief Sidharta mengatakan bahwa "hukum itu ditumbuhkan dan dibutuhkan manusia justru berdasarkan produk penilaian manusia untuk menciptakan kondisi yang melindungi dan memajukan martabat manusia serta untuk memungkinkan manusia menjalani kehidupan yang wajar sesuai dengan martabatnya." 9

Perlindungan hukum masuk dalam ranah hukum publik lebih tepatnya hukum tata negara atau hukum tata pemerintahan, yaitu pemenuhan hak masyarakat atau warga negara yang diperoleh dari negara berupa perlindungan hukum. Semua warga negara mempunyai hak yang sama untuk dapat menikmati keamanan, kenyamanan dan perlindungan hukum yang telah diberikan oleh negara berdasarkan peraturan perundang-undangan.

Ada dua upaya perlindungan hukum yang dapat dilakukan, yaitu Pertama berupa tindakan-tindakan yang diperlukan agar supaya pelanggaran terhadap hak tidak akan terjadi atau disebut dengan pencegahan (preventif). Kedua, upaya perlindungan hukum korektif,

\footnotetext{
7 Juniarso Ridwan, dan Achmad Sodik, Hukum Tata Ruang - dalam konsep kebijakan otonomi daerah, (Bandung: Nuansa, 2008), 114, lihat pula Lily Rasydi dan IB. Wijaya Putra, Hukum Sebagai Suatu Sistem, (Bandung: Remaja Rosda Karya, 1993), 85

8 Ibid., lihat pula Sjachran Basah, Perlindungan Hukum Terhadap Sikap Tindak Administrasi Negara, (Bandung: Alumni, 1992), 13.

${ }_{9}^{9}$ Lili Rasjidi dan B. Arief Sidharta, Filsafat Hukum Madzab dan Refleksi, (Bandung: PT. Remaja Rosda Karya, 1994), 64
} 
yaitu upaya hukum yang dilakukan bilamana pelanggaran hak telah terjadi, maka upaya hukum tidak lagi bersifat preventif, tetapi menjadi bersifat korektifio karena tujuannya melakukan koreksi terhadap akibat-akibat yang terjadi karena adanya perbuatan yang dilakukan oleh pelanggar hak. Upaya hukum korektif dapat bersifat non yudisial karena melibatkan lembaga non peradilan sebagai misal pejabat-pejabat administrasi negara. Upaya hukum yang lain yaitu upaya hukum korektif yang dilakukan oleh lembaga yudisial sehingga telah memasuki proses penegakan hukum (law enforcement). ${ }^{11}$

Dari pendapat Harjono, maka konsep perlindungan hukum yang dibahas oleh beberapa pakar hukum dan dimasukkan dalam sarana perlindungan hukum represif merupakan perlindungan hukum korektif baik yang bersifat non yudisial maupun yang bersifat yudisial. Upaya perlindungan terhadap hak dapat berupa tindakantindakan yang diperlukan agar supaya pelanggaran terhadap hak tidak akan terjadi. Tidak selalu upaya hukum dilakukan melalui jalur yudisial tetapi bisa non yudisial yaitu berupa: peringatan, teguran somasi, keberatan, pengaduan kepada pejabat eksekutif. ${ }^{12}$

Upaya hukum korektif digunakan sesudah (after) adanya pelanggaran dan sekaligus dalam upaya hukum ini terkandung maksud untuk mengembalikan atau memulihkan keadaan setelah terjadinya pelanggaran kepada posisi semula yang benar. ${ }^{13}$ Aspek perlindungan hukum terhadap perempuan (istri) dan anak lebih tepat menggunakan upaya hukum yang bersifat korektif, bilamana perbuatan tersebut sudah terjadi, karena kata korektif terkandung dua nuansa, yaitu nuansa sesudah (after) dan nuansa mengembalikan pada yang benar. ${ }^{14}$

Beberapa hal yang perlu kita kritisi, bahwa anak-anak kita lahir di dunia bukan atas permintaan si anak tetapi atas kehendak kedua orang tuanya (bapak dan ibu), sehingga sudah menjadi kewajiban dari orang tua untuk memberikan penghidupan yang layak sesuai dengan kemampuan dari orang tua. Perlu diingat ada

\footnotetext{
10 Penegak hukum sudah mulai melakukan aktifitasnya

${ }^{11}$ Harjono, Perlindungan Hukum..., 386.

12 Ibid.

13 Ibid., 387.

14 Ibid.
} 
beberapa hak yang melekat pada diri anak sebagaimana disebutkan dalam pasal 4 sampai dengan pasal 18 UU No. 23/2002 tentang Perlindungan Anak, antara lain hak untuk hidup, tumbuh, berkembang dan berprestasi secara wajar sesuai dengan harkat dan martabat kemanusiaan serta mendapat perlindungan dari kekerasan dan diskriminasi. Dari hak yang dimiliki si anak tersebut tentunya ada pihak yang berkewajiban untuk memenuhinya. Pasal 20 UU No. 23/2002 tentang Perlindungan Anak menyatakan bahwa "Negara, pemerintah, masyarakat, keluarga dan orang tua berkewajiban dan bertanggung jawab terhadap penyelenggaraan perlindungan anak".

Perundang-undangan yang selama ini mengatur tentang perlindungan anak dinilai masih kurang dalam hal penegakan hukum dan penerapan hukum. ${ }^{15}$ Perlindungan disini diperlukan karena pada kondisi tertentu perempuan dan anak-anak ini tidak dapat dengan sendirinya melindungi dirinya sehingga dibutuhkan kehadiran orang lain yang dapat memberikan perlindungan atas dirinya.

Menurut H. Muchsin, ada tiga tinjauan aspek hukum perlindungan anak. Pertama, perlindungan dari aspek hukum administrasi negara berupa perlindungan atas kewarganegaraan dan pencatatan kependudukan seperti akte kelahiran, akte adopsi, dan pencatatan lainnya yang berkaitan dengan tertib administrasi. Dalam perlindungan dari aspek administrasi negara ini, pada kasus anak yang lahir dari perkawinan siri, dimana orang tua tidak memiliki akta nikah, maka anak ini tidak mempunyai akta kelahiran. Hal ini disebabkan syarat untuk mendapatkan akta kelahiran selain Kartu Tanda Penduduk kedua orang tua, Kartu Susunan Keluarga, dan Surat Nikah. Kantor Catatan Sipil dan Kependudukan Kabupaten/Kota dapat menerbitkan Akta Kelahiran tanpa menyertakan Surat nikah dan KTP ayah, akan tetapi dalam akta kelahiran akan tertulis anak dari ibu tanpa menyebutkan nama ayah. ${ }^{16}$

15 Tedy Sudrajat, "Perlindungan Hukum Terhadap Hak Anak sebagai Hak Asasi Manusia dalam Perspektif Sistem Hukum Keluarga di Indonesia," Kanun Jurnal Ilmu Hukum, No. 54 Tahun III (Agustus, 2011), 121.

${ }^{16}$ H. Muchsin, Perlindungan Anak Dalam Perspektif Hukum Positif ..., 23. 
Kedua, perlindungan dari aspek hukum perdata yaitu berkaitan dengan hak-hak keperdataan anak seperti hak-hak sipil atau pribadi yang harus diperoleh anak sejak dia lahir termasuk hak asasi manusia. Hak keperdataan ini meliputi hak atas perlindungan terhadap agama, kesehatan, pendidikan, hak sosial, dan perlindungan yang sifatnya khusus/eksepsional. Dalam perlindungan dari aspek perdata, tentunya secara hukum tidak dapat dibuktikan bahwa anak tersebut adalah lahir dari ayah biologis tanpa dapat dibuktikan dalam akta nikah, sehingga hak-hak keperdataan berupa hak atas nafkah, hak atas pendidikan dan hak waris bilamana ayahnya meninggal, maka tidak dapat diperoleh. Sebagaimana diatur dalam Pasal 42 yang menyatakan bahwa "Anak yang sah adalah anak yang dilahirkan dalam atau sebagai akibat perkawinan yang sah". Selanjutnya dalam Pasal 43, menyatakan: (1) Anak yang dilahirkan diluar perkawinan hanya mempunyai hubungan perdata dengan ibunya dan keluarga ibunya; (2) Kedudukan anak tersebut pada ayat (1) diatas selanjutnya akan diatur dalam Peraturan Pemerintah.

Ketiga, perlindungan dari aspek hukum pidana meliputi perlindungan atas tindak kekerasan dan diskriminasi serta perlindungan dari peraturan hukum pidana. Perlindungan dari tindak kekerasan dan diskriminasi, dapat dijabarkan bahwa bentukbentuk tidak terpenuhinya hak-hak anak sudah masuk pada tindak kekerasan terhadap anak. Kekerasan disini meliputi: kekerasan fisik, psikis, dan verbal.

Kekerasan Fisik dapat berupa penelantaran (orang tua tidak memenuhi kewajibannya memberikan nafkah lahir dan batin, pendidikan), terjadinya pemukulan. Kekerasan psikis meliputi perlakuan atau sikap yang menimbulkan anak merasa terancam, tidak nyaman, ada beban berat pada kejiwaan anak. Kekerasan verbal, mengeluarkan kata-kata kotor atau kata-kata yang membuat anak merasa tidak dihargai martabatnya. Pada posisi anak yang dilahirkan dari perkawinan siri pada aspek pidana tentunya akan terjadi yaitu kekerasan fisik dapat berupa penelantaran (orang tua dalam hal ini ayah tidak memenuhi kewajiban memberikan nafkah lahir dan batin serta pendidikan).

Implementasi hak anak sebagai hak asasi manusia dalam perspektif sistem hukum keluarga di Indonesia Pemerintah, 
Pemerintah Daerah, dan Kabupaten/Kota serta penduduk Indonesia berkewajiban memajukan dan melindungi hak-hak anak serta melakukan upaya pemberdayaan yang bermartabat. Oleh karena itu kewajiban tersebut tidak akan berjalan jika tidak ditentukan oleh isi aturan (Content of Law), kesiapan aparatur pemerintah dalam menyelenggarakan isi aturan (Structure of Law), penghargaan masyarakat terhadap isi dan tugas, fungsi pemerintah dalam menyelenggarakan isi aturan (Culture of Law), dan sesuai dengan konstitusi, hukum Islam dan hukum adat. ${ }^{17}$

Istri yang dinikahi melalui perkawinan siri tidak dapat menuntut kepada suami tentang hak-haknya. Hanya kesukarelaan suami untuk berkunjung kepada istri dan anak-anaknya. Istri tidak dapat melakukan tuntutan melalui alat penegak hukum karena alat penegak hukumpun akan dapat memproses secara hukum bilamana ada palaporan/pengaduan warga yang mengalami kekerasan fisik/psikis (termasuk penelantaran, penganiayaan) bilamana dapat dibuktikan secara hukum bahwa mereka mempunyai hubungan keluarga suami, istri, anak-anak ataupun mereka yang hidup dalam lingkup rumah tangga.

Pada kasus yang terjadi di Kecamatan Proppo, Kabupaten Pamekasan, Istri yang dipoligami dengan dinikahi siri lebih banyak tidak tahu dan tidak paham tentang hak-haknya sebagai istri, mereka lebih menerima apa adanya. Hidup dijalani saja kalau terjadi sesuatu akan dipikirkan nanti saja.

\section{Pemahaman Perempuan Pedesaan tentang Poligami dan Perkawinan Siri serta Akibat Hukumnya}

Poligami, merupakan pernikahan yang dijalani oleh 1 (satu) orang laki-laki dengan 2 (dua) orang perempuan atau lebih dalam waktu yang bersamaan. Perdebatan tentang poligami di Indonesia dari masa ke masa tidak pernah berhenti dibicarakan. Selama hokum nasionalnya yang mengatur tentang perkawinan yakni UU No 1 Tahun 1974 masih bercorak abu-abu. Dikatakan bercorak abu-abu karena regulasi negara sesungguhnya berusaha mengatur praktik

\footnotetext{
17 Tedy Sudrajat, "Perlindungan Hukum terhadap Hak Anak sebagai Hak Asasi Manusia," Kanun Jurnal Ilmu Hukum, No. 54, Tahun XIII, (Agustus, 2011), 129.
} 
poligami di Indonesia diatur secara ketat, sebab UU Perkawinan menganut asas monogami. ${ }^{18}$

Praktik poligami yang diatur secara ketat oleh negara pada dasarnya tetap dalam kerangka untuk memberikan perlindungan hukum terutama kaum perempuan dan anak-anak yang berada dalam rumah tangga yang berpoligami. Oleh karena itu ketentuan detailnya dituangkan lebih lanjut dalam Komplasi Hukum Islam (KHI). Persyaratan poligami yang diatur dalam KHI termuat dalam Bab IX dengan judul Beristeri lebih dari satu orang.

Pasal 55 berbunyi: 1.Beristeri lebih dari satu orang pada waktu bersamaan, hanya sampai empat orang isteri; 2 . Syarat utama beristeri lebih dari seorang, suami harus mampu berlaku adil terhadap isteriisteri dan anak-anaknya; dan 3. Apabila syarat utama yang disebutkan pada ayat (2) tidak mungkin terpenuhi, suami dilarang beristeri lebih dari seorang. Pasal 56 berbunyi: 1. Suami yang hendak beristeri lebih dari satu orang harus mendapat izin dari Pengadilan Agama; 2.Pengajuan permohonan izin dimaksud pada ayat (1) dilakukan menurut tata cara yang diatur dalam Bab VIII PP Nomor 9 Tahun 1975; dan 3. Perkawinan yang dilakukan dengan isteri kedua, ketiga atau keempat tanpa izin dari Pengadilan Agama, tidak mempunyai kekuatan hukum.

Mengingat persyarakat dalam berpoligami sangat ketat, maka para pelaku poligami yang tentunya tidak dapat memenuhi persyaratan tersebut akan memilih dengan cara melakukan perkawinan siri atau dibawah tangan walaupun sudah mengetahui bahwa perkawinan yang dilakukan tidak mempunyai perlindungan dan kekuatan hukum.

Pernikahan siri atau sering juga diartikan oleh masyarakat umum dengan nikah bawah tangan adalah Pertama, pernikahan tanpa wali. Artinya pernikahan tersebut tidak dihadiri oleh pihak wali karena tidak mendapat perstujuan wali, atau hanya karena ingin memuaskan nafsu syahwat belaka tanpa mengindahkan lagi ketentuan-ketentuan yang ditetapkan syari'at. Kedua; pernikahan yang sah secara agama, namun tidak dicatatkan secara resmi pada

18 Shinta Dewi Rismawati, “Persepsi Poligami Di Mata Perempuan Pekalongan," Jurnal MUWÂZÂH, Vol. 6, No. 2, Desember 2014, 249. 
instansi berwenang sebagaimana diatur dalam perturan perundangundangan negara. Ketiga; pernikahan yag sudah dicatat, tetapi masih dirahasiakan atau belum diresmikan secara terbuka kepada khalayak karena pertimbangan-pertimbangan tertentu. ${ }^{19}$

Jika syarat dan rukun nikah sudah terpenuhi, akan tetapi tidak dilakukan pencatatan dengan berbagai alasan karena ada penghalang menurut ketentuan Undang-undang, meskipun nikah tersebut dinilai sah, namun Rasul menyuruh masyarakat yang menikah untuk mengumumkan pernikahannya dengan walimah (kenduri/syukuran), guna untuk menghindari dari fitnah. Selain dapat menimbulkan dampak negatif, nikah siri dapat pula menimbulkan dosa bagi pelakunya, karena melanggar ketentuan yang ditetapkan oleh pemerintah (ulul amri). Sementara al-Quran memerintahkan setiap muslim untuk menta'ati ulu al-amr selama tidak bertentangan dengan hukum Allah. Dalam hal pencatatan tersebut, ia bukan saja tidak bertentangan, tetapi justru sejalan dengan semangat al-Quran. ${ }^{20}$

Perempuan Kecamatan Proppo, Kabupaten Pamekasan yang dipoligami dan dinikahi siri, mayoritas mereka sudah paham bahwa poligami itu adalah seorang laki-laki yang menikah lebih dari satu pada saat yang bersamaan. Mereka juga paham bahwa pernikahan Siri yaitu pernikahan yang hanya dilaksanakan dihadapan kyai dan tidak dicatatkan serta tidak mempunyai akta nikah. Akibat dari tidak mempunyai akta nikah, maka tidak dapat menuntut hak-haknya, baik hak atas istri maupun hak-hak terhadap anak mereka.

Dengan menggunakan teori Roscoe Poud, yang dalam pendapatnya tentang hukum: "Law is a tool of a social engineering", ${ }^{21}$ yang juga sama dengan pandangan Mochtar Kusumaatmadja bahwa hukum itu merubah masyarakat. Fungsi hukum menurut Roscoe Poud tidak hanya berfungsi mengatur, tetapi juga harus berfungsi membangun masyarakat. Bila dilihat dari perspektif politik hukum, maka hukum berasal dari atas ke bawah (top down) maksudnya disini adalah hukum itu berasal dari pemerintah

${ }^{19}$ Ali Akbar, "Nikah Sirri Menurut Perspektif Al-Quran," Jurnal Ushuluddin, Vol. XXII No. 2, Juli 2014, 217.

20 Ibid.

21 Mochtar Kusumaatmadja, Konsep-konsep Hukum dalam Pembangunan, (Bandung: PT.Alumni, 2002), 14 
untuk dijalankan oleh masyarakat karena hukum butuh regulasi dari pemerintah. Teori Roscoe Poud ini yang pada kenyataannya saat ini diterapkan dalam pembentukan hukum di Indonesia.

Tujuan dari Teori Roscoe Poud ini, bahwa perempuan yang dipoligami dan dinikahi siri paham akan perkawinan yang dilakukan bahwa sebuah pelanggaran namun kasus seperti ini terus menerus terjadi bahkan mengancam hak-hak yang seharusnya diterima oleh dirinya dan juga anak-anaknya. Dibutuhkannya peraturan yang bersifat memaksa dari pemerintah untuk dapat melakukan perubahan terhadap perilaku masyarakat tersebut.

Pengaturan pemerintah yang seharusnya lebih tegas dan segera dalam rangka membendung praktik poligami liar yang semakin marak terjadi. Korban yang paling banyak terjadi adalah anak-anak, kemana anak-anak harus mendapatkan perhatian, kasih sayang dan perlindungan. Hasil penelitian penulis menunjukkan bahwa $75 \%$ (tujuh puluh lima prosen) Anak Yang Berhadapan dengan Hukum $(\mathrm{ABH})$ terjadi pada anak-anak broken home. Kurang atau tidak adanya perhatian dan kasih sayang dalam keluarga sebagai faktor utama terjadinya $\mathrm{ABH}$, terutama anak sebagai pelaku. Reformasi terhadap UU No. 1 Tahun 1974 tentang Perkawinan menjadi harapan untuk mempertegas legalitas perkawinan serta dalam rangka memberikan perlindungan kepada perempuan dan anak.

\section{Kondisi Rumah Tangga Perempuan Pedesaan sebagai Isteri Poligami dengan Status Pernikahan Siri}

Perempuan Desa Rangperang Daya dan Desa Klampar

Kecamatan Proppo, Kabupaten Pamekasan bersedia dipoligami dan dinikahi siri, ada beberapa faktor yang melatar belakangi, yaitu pertama dilatar belakangi keterpaksaan karena tidak ada yang menikahi, sehingga khawatir menjadi perawan tua. Anggapan masyarakat bahwa jika sudah mencapai usia 20 tahun tidak ada yang melamar adalah aib, malu sama tetangga itu lebih besar dari pada menikah dengan cara yang melanggar aturan Undang-Undang. Perempuan pedesaan yang masih memegang kebiasaan atau kultur masyarakat partiarchi, menganggap laki-laki atau suami boleh saja melakukan sesuatu apapun yang dia kehendaki walaupun ada hakhak perempuan atau istri dan anak yang diabaikan. Hal semacam ini 
mendapat dukungan dari lingkungan masyarakat dan keluarga, sehingga jika ada laki-laki yang masih tunduk dengan kemauan perempuan atau istri dianggap laki-laki kalah atau nespa.

Kedua, dilatar belakangi suka-sama suka, saling mencintai walaupun suami sudah punya istri hal ini tidak diperdulikan. Bahkan yang memprihatinkan bukan hanya akad perkawinan yang dilanggar tapi sendi-sendi kehidupan bermasyarakat dan agamapun juga dilanggar. Mereka sudah hidup dalam satu rumah tanpa ikatan perkawinan. Dalam menganalisa fokus ketiga ini digunakan teori Teori Roscoe Poud, dengan maksud praktik seperti ini tidak lagi terus menerus hidup dan berkembang di masyarakat akan tetapi harus terjadi perubahan dan untuk itu diperlukan alat pemaksa dari pemerintah yang sifatnya top down. Ciri yang menonjol dari hukum pada masyarakat modern, adalah pengunaannya secara sadar oleh masyarakatnya. Di sini hukum tidak hanya di pakai untuk mengukuhkan pola-pola kebiasaan dan tingkah laku yang terdapat dalam masyarakat melainkan juga untuk mengarahkannya kepada tujuan-tujuan yang dikehendaki, menghapus kebiasaan yang dipandangnya tidak sesuai lagi, menciptakan pola-pola kelakuan baru dan sebagainnya. ${ }^{22}$

Walaupun pernikahan siri tidak memiliki status hukum di hadapan Negara, akan tetapi pada dasarnya sifat dari tuntutan pidana adalah mencari kebenaran materiil. Oleh karena itu, si lakilaki dapat saja dijerat dengan hukum pidana, selama si perempuan dapat membuktikan bahwa perkawinan sebelumnya memang ada. Apabila terdapat bukti-bukti yang cukup untuk membuktikan adanya perkawinan tersebut (misalnya kesaksian dari kyai yang menikahkan, saksi dan lain-lain), maka laki-laki dapat dijerat atas kejahatan terhadap asal usul dan perkawinan sebagaimana diatur dalam KUHP Pasal 279. 23

22 Shinta Dewi Rismawati, Pembangunan Hukum Yang Berkeadilan Gender (Pendekatan Studi Hukum Kritis Bagi Perlindungan Hak Asasi Perempuan Di Indonesia Pasca Ratifikasi CEDAW), Jurnal MUWÂZÂH Vol. 3, No. 2, Desember 2011, 438.

23 (1) Diancam dengan pidana penjara paling lama lima tahun: 1.Barang siapa mengadakan perkawinan padahal mengetahui bahwa perkawinan atau perkawinan-perkawinannya yang telah ada menjadi penghalang yang sah untuk itu; 2. Barang siapa mengadakan perkawinan padahal mengetahui bahwa perkawinan atau perkawinan-perkawinan pihak lain menjadi penghalang untuk itu. 
Mengenai pasal 279 KUHP ini, R. Soesilo dalam bukunya yang berjudul Kitab Undang-Undang Hukum Pidana (KUHP) Serta KomentarKomentarnya Lengkap Pasal Demi Pasal, menjelaskan bahwa suatu syarat supaya orang dapat dihukum menurut pasal ini ialah orang itu harus mengetahui, bahwa ia dulu pernah kawin dan perkawinan ini masih belum dilepaskan (belum ada perceraian). Oleh karena itu, laki-laki dapat dikenakan pidana berdasarkan Pasal 279 KUHP selama bisa dibuktikan bahwa memang sebelumnya telah ada perkawinan. Delik dalam pasal 279 KUHP bersifat delik aduan. Posisi istri menjadi lemah jika sumber pendapatan hanya dari suami, disini lagi-lagi perempuan ada pada kondisi dilematik, disatu sisi menginginkan keadilan namun disisi lain ekonomi keluarga menjadi taruhan.

Ketiga, Masyarakat Kecamatan Proppo, Kabupaten Pamekasan ada yang berada diluar negeri dalam rangka untuk bekerja baik laki-laki maupun perempuan. Kehidupan diluar negeri yang jauh dari istri atau suami tentunya menjadi persoalan sendiri. Sehingga banyak para Tenaga Kerja Indonesia (TKI) yang menikah diluar negeri dengan sesama TKI, mereka cukup menikah didepan kyai di luar negeri dan sesampainya di Indonesia ada yang terus berlanjut menjadi pasangan suami istri tapi juga banyak yang berpisah. Praktik seperti ini bukan lagi rahasia tapi sudah menjadi pengetahuan umum. Bahkan perempuan yang bekerja di luar negeri tanpa didampingi muhrimnya menjadi sangat rawan, sehingga para perempuan akan memilih menikah dengan laki-laki di luar negeri dalam rangka menjaga keamanan. Persoalan terbesar akan terjadi jika mereka kembali ke Indonesia, istri atau suami yang mengetahui peristiwa ini banyak yang mengajukan perceraian di Pengadilan Agama.

Kondisi rumah tangga perempuan pedesaan sebagai istri poligami dengan status pernikahan siri bahwa rumah yang ditempati rata-rata rumah orang tua, perabotan rumah tangga, cukup sebagai standar rumah di pedesaan. Ketercukupan sandang dan makan juga rata-rata cukup, itupun bukan saja dari suami hasil perkawinannya

(2) Jika yang melakukan perbuatan berdasarkan ayat 1 butir 1 menyembunyikan kepada pihak lain bahwa perkawinan yang telah ada menjadi penghalang yang sah untuk itu diancam dengan pidana penjara paling lama tujuh tahun.

(3) Pencabutan hak berdasarkan pasal 1 - 5 dapat dinyatakan. 
tetapi dari hasil kerja perempuan sendiri dan peninggalan mantan suami pertama.

Untuk membahas kebutuhan minimal hidup manusia, tentunya kita harus menggunakan rujukan tentang Standar Kebutuhan Hidup Layak (KHL) yang telah ditetapkan oleh pemerintah. Standar KHL adalah dasar dalam penetapan Upah Minimum. Kebutuhan Hidup Layak adalah standar kebutuhan yang harus dipenuhi oleh seseorang untuk dapat hidup layak baik secara fisik, non fisik dan sosial, untuk kebutuhan 1 (satu) bulan.

Sejak diundangkan UU No. 13/2003 tentang Ketenagakerjaan, Pemerintah menetapkan standar KHL sebagai dasar dalam penetapan Upah Minimum seperti yang diatur dalam pasal 88 ayat (4), yang menyatakan bahwa "Pemerintah menetapkan upah minimum sebagaimana dimaksud dalam ayat (3) huruf a berdasarkan kebutuhan hidup layak dan dengan memperhatikan produktivitas dan pertumbuhan ekonomi". Pembahasan lebih dalam mengenai ketentuan KHL, diatur dalam Keputusan Menteri Tenaga Kerja No. 17/2005 tentang Komponen dan Pentahapan Pencapaian Kebutuhan Hidup Layak. Namun, Keputusan Menteri Tenaga Kerja No. 17/2005 direvisi oleh Keputusan Menteri Tenaga Kerja No. 13/2012 tentang Perubahan Penghitungan KHL. Komponen yang termasuk dalam standar KHL, terdiri dari: makanan dan minuman, sandang, perumahan, pendidikan, kesehatan, transportasi, rekreasi dan tabungan.

\begin{tabular}{|c|l|c|c|}
\hline \multicolumn{1}{|c|}{ Komponen } & Kualitas/Kriteria & $\begin{array}{c}\text { Jumlah } \\
\text { Kebutuhan }\end{array}$ \\
\hline I & \multicolumn{1}{|c|}{$\begin{array}{c}\text { MAKANAN DAN } \\
\text { MINUMAN }\end{array}$} & \\
\hline 1 & Beras Sedang & Sedang & $10 \mathrm{~kg}$ \\
\hline 2 & Sumber Protein : & Sedang & $0.75 \mathrm{~kg}$ \\
\hline & a. Daging & Baik & $1.2 \mathrm{~kg}$ \\
\hline & b. Ikan Segar & Telur ayam ras & $1 \mathrm{~kg}$ \\
\hline & c. Telur Ayam & Baik & $4.5 \mathrm{~kg}$ \\
\hline 3 & Kacang-kacangan : tempe/tahu & Sedang & $0.9 \mathrm{~kg}$ \\
\hline 4 & Susu bubuk & Sedang & $3 \mathrm{~kg}$ \\
\hline 5 & Gula pasir & Curah & $2 \mathrm{~kg}$ \\
\hline 6 & Minyak goring & Baik & $7.2 \mathrm{~kg}$ \\
\hline 7 & Sayuran & & \\
\hline
\end{tabular}




\begin{tabular}{|c|c|c|c|}
\hline 8 & $\begin{array}{l}\text { Buah-buahan (setara } \\
\text { pisang/pepaya) }\end{array}$ & Baik & $7.5 \mathrm{~kg}$ \\
\hline 9 & $\begin{array}{l}\text { Karbohidrat lain (setara tepung } \\
\text { terigu) }\end{array}$ & Sedang & $3 \mathrm{~kg}$ \\
\hline 10 & Teh atau Kopi & Celup/Sachet & $\begin{array}{c}2 \text { Dus isi } 25= \\
75 \text { gr }\end{array}$ \\
\hline \multirow[t]{2}{*}{11} & Bumbu-bumbuan & Nilai $1 \mathrm{~s} / \mathrm{d} 10$ & $15 \%$ \\
\hline & JUMLAH & & \\
\hline II & SANDANG & & \\
\hline 12 & $\begin{array}{l}\text { Celana panjang/ Rok/Pakaian } \\
\text { muslim }\end{array}$ & Katun/sedang & $6 / 12$ potong \\
\hline 13 & Celana pendek & Katun/sedang & 2/12 potong \\
\hline 14 & Ikat Pinggang & $\begin{array}{c}\text { Kulit sintetis, } \\
\text { polos, tidak } \\
\text { branded }\end{array}$ & $1 / 12$ buah \\
\hline 15 & Kemeja lengan pendek/blouse & Setara katun & $6 / 12$ potong \\
\hline 16 & Kaos oblong/ BH & Sedang & $6 / 12$ potong \\
\hline 17 & Celana dalam & Sedang & $6 / 12$ potong \\
\hline 18 & Sarung/kain panjang & Sedang & 1/12 helai \\
\hline 19 & Sepatu & Kulit sintetis & 2/12 pasang \\
\hline 20 & Kaos Kaki & $\begin{array}{l}\text { Katun, Polyester, } \\
\text { Polos, Sedang }\end{array}$ & 4/12 pasang \\
\hline \multirow[t]{3}{*}{21} & $\begin{array}{l}\text { Perlengkapan pembersih } \\
\text { sepatu }\end{array}$ & & \\
\hline & a. Semir sepatu & Sedang & $6 / 12$ buah \\
\hline & b. Sikat sepatu & Sedang & $1 / 12$ buah \\
\hline 22 & Sandal jepit & Karet & 2/12 pasang \\
\hline 23 & Handuk mandi & $100 \mathrm{~cm} \times 60 \mathrm{~cm}$ & 2/12 potong \\
\hline \multirow[t]{5}{*}{24} & Perlengkapan ibadah & & \\
\hline & a. Sajadah & Sedang & $1 / 12$ potong \\
\hline & b. Mukena & Sedang & $1 / 12$ potong \\
\hline & c. Peci,dll & Sedang & 1/12 potong \\
\hline & JUMLAH & & \\
\hline III & $\begin{array}{l}\text { PERUMAHAN } \\
\end{array}$ & & \\
\hline 25 & Sewa kamar & $\begin{array}{c}\text { dapat } \\
\text { menampung jenis } \\
\text { KHL lainnya }\end{array}$ & 1 bulan \\
\hline 26 & Dipan/ tempat tidur & No.3, polos & $1 / 48$ buah \\
\hline \multirow[t]{2}{*}{27} & Perlengkapan tidur & & \\
\hline & a. Kasur busa & Busa & $1 / 48$ buah \\
\hline
\end{tabular}


Umi Supraptingsih

\begin{tabular}{|c|c|c|c|}
\hline & b. Bantal busa & Busa & $2 / 36$ buah \\
\hline 28 & Sprei dan sarung bantal & Katun & $2 / 12$ set \\
\hline 29 & Meja dan kursi & 1 meja/4 kursi & $1 / 48$ set \\
\hline 30 & Lemari pakaian & Kayu sedang & $1 / 48$ buah \\
\hline 31 & Sapu & Ijuk sedang & $2 / 12$ buah \\
\hline \multirow[t]{4}{*}{32} & Perlengkapan makan & & \\
\hline & a. Piring makan & Polos & $3 / 12$ buah \\
\hline & b. Gelas minum & Polos & $3 / 12$ buah \\
\hline & c. Sendok garpu & Sedang & 3/12 pasang \\
\hline 33 & Ceret aluminium & Ukuran $25 \mathrm{~cm}$ & $1 / 24$ buah \\
\hline 34 & Wajan aluminium & Ukuran $32 \mathrm{~cm}$ & $1 / 24$ buah \\
\hline 35 & Panci aluminium & Ukuran $32 \mathrm{~cm}$ & $2 / 12$ buah \\
\hline 36 & Sendok masak & Alumunium & $1 / 12$ buah \\
\hline 37 & Rice Cooker ukuran $1 / 2$ liter & 350 watt & $1 / 48$ buah \\
\hline \multirow[t]{4}{*}{38} & Kompor dan perlengkapannya & & \\
\hline & a. Kompor 1 tungku & SNI & $1 / 24$ buah \\
\hline & b. Selang dan regulator & SNI & 10 liter \\
\hline & c. Tabung Gas $3 \mathrm{~kg}$ & Pertamina & $1 / 60$ buah \\
\hline 39 & Gas Elpiji & $\begin{array}{c}\text { Masing-masing } 3 \\
\text { kg }\end{array}$ & 2 tabung \\
\hline 40 & Ember plastic & Isi 20 liter & $2 / 12$ buah \\
\hline 41 & Gayung plastic & Sedang & $1 / 12$ buah \\
\hline 42 & Listrik & 900 watt & 1 bulan \\
\hline 43 & Bola lampu hemat energi & 14 watt & $3 / 12$ buah \\
\hline 44 & Air Bersih & Standar PAM & 2 meter kubik \\
\hline 45 & Sabun cuci pakaian & Cream/deterjen & $1.5 \mathrm{~kg}$ \\
\hline 46 & Sabun cuci piring (colek) & $500 \mathrm{gr}$ & 1 buah \\
\hline 47 & Setrika & 250 watt & $1 / 48$ buah \\
\hline 48 & Rak portable plastik & Sedang & $1 / 24$ buah \\
\hline 49 & Pisau dapur & Sedang & $1 / 36$ buah \\
\hline \multirow[t]{2}{*}{50} & Cermin & $30 \times 50 \mathrm{~cm}$ & $1 / 36$ buah \\
\hline & JUMLAH & & \\
\hline IV & PENDIDIKAN & & \\
\hline 51 & Bacaan/radio & Tabloid/4 band & 4 buah/ (1/48) \\
\hline \multirow[t]{2}{*}{52} & Ballpoint/pensil & Sedang & $6 / 12$ buah \\
\hline & JUMLAH & & \\
\hline $\mathbf{V}$ & KESEHATAN & & \\
\hline \multirow[t]{3}{*}{53} & Sarana Kesehatan & & \\
\hline & a. Pasta gigi & 80 gram & 1 tube \\
\hline & b. Sabun mandi & 80 gram & 2 buah \\
\hline
\end{tabular}




\begin{tabular}{|c|c|c|c|}
\hline & c. Sikat gigi & Produk local & $3 / 12$ buah \\
\hline & d. Shampo & Produk local & 1 botol $100 \mathrm{ml}$ \\
\hline & e. Pembalut atau alat cukur & Isi 10 & $1 \mathrm{dus} / \mathrm{set}$ \\
\hline 54 & Deodorant & $100 \mathrm{ml} / \mathrm{g}$ & $6 / 12$ botol \\
\hline 55 & Obat anti nyamuk & Bakar & 3 dus \\
\hline 56 & Potong rambut & $\begin{array}{l}\text { Di tukang } \\
\text { cukur/salon }\end{array}$ & 6/12 kali \\
\hline \multirow[t]{2}{*}{57} & Sisir & Biasa & 2/12 buah \\
\hline & JUMLAH & & \\
\hline VI & TRANSPORTASI & & \\
\hline \multirow[t]{2}{*}{58} & Transportasi kerja dan lainnya & Angkutan umum & 30 hari $(\mathrm{PP})$ \\
\hline & JUMLAH & & \\
\hline VII & $\begin{array}{c}\text { REKREASI DAN } \\
\text { TABUNGAN }\end{array}$ & & \\
\hline 59 & Rekreasi & Daerah sekitar & 2/12 kali \\
\hline \multirow[t]{3}{*}{60} & Tabungan & $\begin{array}{c}\text { (2\% dari nilai } 1 \\
\text { s/d 59) }\end{array}$ & $2 \%$ \\
\hline & JUMLAH & & \\
\hline & $\begin{array}{l}\text { JUMLAH (I + II + III + IV + V + } \\
\text { VI + VII })\end{array}$ & & \\
\hline
\end{tabular}

Dari hasil sumber data primer penelitian berupa observasi, didapatkan bahwa perempuan yang dipoligami dan dinikahi siri serta anak-anaknya dalam pemenuhan kebutuhan minimal hidup hanyalah kebutuhan makan dan minum saja. Untuk mencukupi kebutuhan makan dalam satu hari mereka dapatkan sebanyak 3 (tiga) kali.

Penghasilan yang mereka peroleh dalam tiap hari rata-rata $\mathrm{Rp}$ 15.000 (lima belas ribu rupiah) sampai dengan Rp 30.000 (tiga puluh ribu rupiah) sehingga kalau dibuat rata-rata pendapatan mereka tiap orang dalam satu bulan rata-rata $\mathrm{Rp} 600.000$ (enam ratus ribu rupiah) sampai Rp 900.000. (Sembilan ratus ribu rupiah). Bilamana kita lihat upah minimum kabupaten pekerja di Kab. Pamekasan sebesar Rp 1.209.900 (satu juta dua ratus Sembilan ribu Sembilan ratus rupiah) tiap bulan. Uang belanja pemberian suami tidak dapat diharapkan secara rutin tiap hari ataupun tiap bulan karena hanya sewaktuwaktu saja memberinya.

Kebutuhan sandang/pakaian mereka kurang atau bahkan tidak diperhatikan, dalam satu tahun mereka hanya membeli satu kali sampai dua kali saja bertepatan dengan lebaran. Mengingat 
pemenuhan kebutuhan hidup sehari-hari tidak dapat dihindari sedangkan penghasilan yang relatif belum dapat mencukupi, maka kehidupan mereka sangat jauh dari kecukupan. Itu gambaran secara kongkrit pemenuhan kebutuhan hidup istri yang dipoligami dengan perkawinan siri serta anak-anak mereka.

Sikap dari masyarakat lingkungan juga tidak baik, masyarakat menilai bahwa perempuan tersebut telah mengganggu dan merebut suami orang, sehingga cibiran dan cemoohan terjadi pada mereka termasuk anak-anak mereka.

\section{Kesimpulan}

Berdasarkan hasil pembahasan tersebut, maka dapat disimpulkan sebagai berikut

Pertama Perlindungan hukum terhadap anak serta perempuan yang dipoligami dan dinikahi siri, tidak diperoleh baik perlindungan dalam bidang administrasi, perdata maupun pidana. Secara hukum istri dan anak tidak dapat membuktikan bahwa mereka adalah suami istri yang dibuktikan dengan akta nikah, begitu pula atas anak yang dilahirkan dari perkawinan siri, tidak dapat dibuktikan secara hukum atas hubungan anak dengan ayah. Istri dan anak tidak dapat menuntut kepada suami atau ayah tentang hakhaknya, seperti hak untuk mendapatkan pangan, sandang, papan, dan pendidikan serta hak untuk dikunjungi dalam waktu tertentu.

Kedua Perempuan yang dipoligami dan dinikahi siri faham bahwa, poligami adalah seorang laki-laki yang menikah lebih dari satu pada saat yang bersamaan. Pernikahan Siri yaitu pernikahan yang hanya dilaksanakan dihadapan kyai dan tidak mempunyai surat nikah. Mereka juga paham bahwa pernikahan yang dilakukan melanggar peraturan perundang-undangan. Begitu pula akibat hukum dari pelanggaran tersebut yaitu kehilangan hak-hak atas dirinya dan keturunannya.

Ketiga Latar belakang perempuan pedesaan bersedia dipoligami dan dinikahi siri yaitu karena keterpaksaan khawatir tidak ada yang menikahi, suka-sama suka, saling mencintai, dan karena bertemu di luar negeri, karena sama-sama bekerja di luar negeri. Keempat Kondisi rumah tangga perempuan pedesaan sebagai isteri poligami dengan status pernikahan siri rata-rata rumah yang ditempati adalah rumah orang tua, begitu pula dengan perabotan rumah tangga, 
sangat sederhana sebagai standart rumah di pedesaan. Mereka hanya dapat makan dan minum seadanya. Ketercukupan sandang dan makan juga rata-rata cukup, itupun bukan saja dari suami yang mempoligami tapi dari hasil bekerja sendiri dan peninggalan mantan suami.

\section{Daftar Pustaka}

Akbar, Ali, Nikah Siri Menurut Perspektif Al-Quran, Jurnal Ushuluddin Vol. XXII No. 2, Juli 2014

Al-Hamid, Zaid Hesein, Pendidikan Anak Menurut Islam, Jakarta: Pustaka Amani, 1987

Asse, Ambo, Pernikahan di Bawah Tangan (Nikah Siri) Termasuk Perbuatan Melawan Hukum, Varia Peradilan - Majalah Hukum Tahun XXIX No. 344 Juli 2014

Basah, Sjachran, Perlindungan Hukum Terhadap Sikap Tindak Administrasi Negara, Bandung: Alumni, 1992

Dewi, Shinta Rismawati, Model Konstruksi Hukum Hakim dalam Putusan Kasus Kekerasan dalam Rumah Tangga, Jurnal Penelitian, Vol. 6 No. 2, Nopember 2009

Dewi, Shinta Rismawati, Persepsi Poligami di Mata Perempuan Pekalongan, Jurnal MUWÂZÂH, Volume 6, Nomor 2, Desember 2014

Dewi, Shinta Rismawati, Pembangunan Hukum Yang Berkeadilan Gender (Pendekatan Studi Hukum Kritis Bagi Perlindungan Hak Asasi Perempuan Di Indonesia Pasca Ratifikasi CEDAW), Jurnal MUWÂZÂH Volume 3, Nomor 2, Desember 2011

Haddad, Yakan Muna, Hati-hati Terhadap Media yang Merusak Anak, Jakarta: Gema Insani Press, 1992

Harjono, Perlindungan Hukum (Membangun sebuah Konsep Hukum)

- dalam Konstitusi Sebagai Rumah Bangsa, (Jakarta: Sekretariat Jenderal dan Kepaniteraan Mahkamah Konstitusi, 2008

H.R. Abdussalam, Hukum Perlindungan Anak, Jakarta: Restu Agung, 2007

Kusumaatmadja, Mochtar. Konsep-konsep Hukum dalam Pembangunan, Bandung: PT. Alumni, 2002

Latifah, Hambatan Budaya Dalam Kesehatan Anak, Musawa - Jurnal Studi Gender dan Islam, Vol. 4 No. 2, Juli 2006 
Umi Supraptingsih

M. Hadjon, Philipus, Perlindungan Rakyat Bagi Rakyat di Indonesia (Sebuah Studi tentang Prinsip-Prinsipnya, Penanganannya oleh Pengadilan dalam Lingkungan Peradilan Umum dan Pembentukan Peradilan Administrasi Negara), Surabaya: PT. Bina Ilmu, 1987

Malahayati dkk, Konsep Perlindungan Hukum dan Hak Asasi Manusia Terhadap Penata Laksana Rumah Tangga di Indonesia, Jurnal Nanggroe, Vol. 4 No. 1 (April 2015), Bagian Hukum Tata Negara Universitas Malikussaleh

Marzuki, Peter Mahmud, Penelitian Hukum, Jakarta: Kencana Prenada Media Group, 2005

Muhadjir, Noeng, Metode Penelitian Kualitatif, Yogyakarta: Rake Sarasin, 1996

Muchsin, H, Perlindungan Anak Dalam Perspektif Hukum Positif (Tinjauan Hukum Administrasi Negara, Hukum Perdata, dan Hukum Pidana), Varia Peradilan - Majalah Hukum Tahun XXVI No. 308 Juli 2011

Mulia, Siti Musdah, Islam dan Inspirasi Kesetaraan Gender, Yogyakarta: Kibar Press, 2007

Muthahhari, Murtadha, Hak-Hak Wanita dalam Islam, Jakarta: PT. Lentera Baritama, 2001

S. Nasution, Metode Research, Jakarta: Bumi Aksara, 1996

Nonet, Philippe dan Philip Selznick, Hukum Responsif, diterjemahkan dari Law and Society in Transition oleh Raisul Muttaqien, Bandung: Nusamedia, 2007

Parawansa, Khofifah Indar, Mengukir Paradigma enembus Tradisi Pemikiran tentang Kesetaraan Jender, Jakarta: LP3ES, 2006

Prawirohamidjojo, R. Soetojo, Pluralisme Dalam Perundangundangan Perkawinan di Indonesia, Surabaya: Airlangga University Press, 2006

Rasjdi, Lili dan IB. Wijaya Putra, Hukum Sebagai Suatu Sistem, Bandung: Remaja Rosda Karya, 1993

Rasjidi, Lili dan B. Arief Sidharta, Filsafat Hukum Madzab dan Refleksi, Bandung: PT. Remaja Rosda Karya, 1994

Ridwan, Juniarso, dan Achmad Sodik, Hukum Tata Ruang - dalam konsep kebijakan otonomi daerah, Bandung: Nuansa, 2008,

Sudrajat, Tedy, Perlindungan Hukum terhadap Hak Anak sebagai Hak Asasi Manusia, Kanun Jurnal Ilmu Hukum No. 54, Th. XIII (Agustus, 2011). 
Sudrajat, Tedy, Perlindungan Hukum Terhadap Hak Anak Sebagai Hak Asasi Manusia Dalam Perspektif Sistem Hukum Keluarga Di Indonesia, Kanun Jurnal Ilmu Hukum, No. 54 Tahun III (Agustus, 2011)

Syaltut, Mahmud, Min Taujihat Al-Islam, Kairo: Al-Idarat Al-`Amat lil Azhar, 1959,

Syamsuddin, Sahiron, Islam Tradisi dan Peradaban, Yogyakarta: Bina Mulia Press bekerjasama dengan SUKA Press UIN Sunan Kalijaga, 2012

Utsman, Sabian, Menuju Penegakan Hukum Responsif - Konsep Phillippe Nonet dan Philip Selznick Perbandingan Civil Law System $\mathcal{E}$ Common Law System Spiral Kekerasan \& Penegakan Hukum, Yogyakarta: Pustaka, 2008

Wasman dan Wardah Nuroniyah, Hukum Perkawinan Islam di Indonesia, Yogyakarta: Teras, 2011

Wahid, Abdurrahman, Islam Tanpa Kekerasan, Yogyakarta: LKiS, 1998

Badan Penasehat Pembinaan dan Pelestarian Perkawinan Propinsi Jawa Timur, Tuntunan Praktis Rumah Tangga Bahagia, Surabaya: tp, 1993

Badan Pusat Statistik Kabupaten Pamekasan, Kabupaten Pamekasan Dalam Angka, tahun 2009

Departemen Agama RI, Al-Qur'an dan Terjemahnya, Surabaya: CV. Aisyiah, 1998 